\title{
Construction of Hevea brasiliensis Genetic Linkage Map and Identification of Quantitative Trait Loci Using RAPD Markers
}

\author{
Novalina $^{\#}$, Aidi Daslin Sagala* \\ \# Faculty of Agriculture, Jambi University, Kampus Pinang Masak Mendalo Darat Jambi Indonesia \\ E-mail: novalina.pertanian@gmail.com \\ * Rubber Research Center, Sei Putih Medan Indonesia
}

\begin{abstract}
Rubber breeding program so far have constraints especially in selection process which need very wide area and very long time. The use molecular markers in breeding program could simplify the selection procedure. The objectives of research were to get the linkage map especially for PB 260 as female parent, and to get RAPD markers and morphology markers which associated with QTL controlling production component. Construction of genetic linkage map on rubber tree $(2 \mathrm{n}=36)$ was conducted by using RAPD markers data through pseudo-testcross. First generation progenies of crossing between PB 260 and PN were used as mapping populations: 22 progenies of A population (PB $260 \times$ PN 7111), 20 progenies of C population (PB 260 x PN7). Construction of linkage map was conducted using MAPMAKER/EXP 3.0. Linkage map of PB 260 was constructed on LOD 3.0 yielded 1 linkage group, on LOD 2.5 yielded 2 linkage group. Based on single marker analysis through t-test was known that marker C13-2000 linked with yield character and number of latex vessel character. Character of leaf shape linked with girth, bark thickness, and number of latex vessel. Character of leaf edge linked with plugging index.
\end{abstract}

Keywords - Genetic Linkage Map; Rapd Markers; Qtl; First Generation Population of Rubber Tree; Double Pseudo-Testcross.

\section{INTRODUCTION}

Rubber breeding program so far have constraints especially in selection process which need very wide area and very long time. A strategy that could be used to overcome the problem is through marker assisted selection (MAS). Using molecular marker techniques in plant breeding program is expected to be able to shorten the time and reduce the selection area. The availability of a genetic linkage map is requirements that are needed in the process of marker-assisted selection [1]. Marker-assisted selection process could be done if it has been localized quantitative trait loci (QTLs) which linked with molecular markers or simple traits. The procedures for finding the QTLs are called QTL mapping. QTL mapping involves construction of genetic maps and searching for a relationship between quantitative traits and polymorphic markers.

The QTL is determined to be located near a marker if phenotipic values for the trait are significantly different among the marker genotypes. If there is a significantly association between the quantitative trait and the marker it may be evidence of a QTL near the marker [2]. Basically, a genetic linkage map can be constructed by using backcross or F2 segregation population derived from crosses between inbred lines. Such populations are generally not available in rubber plant and are difficult to obtain due to time constrains and a significant genetic load. So, the double testcross mapping strategy could be used to construct genetic linkage maps in rubber plant, as in [3]. In such strategy, female parent is as a tester for male parent and just the opposite so that it is obtained two linkage maps i.e. a female parent linkage map and a male parent linkage map.

Heterozygous-genotyping markers in a parent and homozygous recessive in another parent are selected through screening segregation ratio $1: 1$ on their progenies. In this strategy, genetic map can be constructed by using first generation of a crossing. First generation population have been widely used as a mapping population for constructing linkage maps [3], [4] [5], [6], [7]. Genetic linkage maps could be obtained through DNA-based markers such as RFLP, AFLP, SSR and RAPD.

Molecular marker technology which is known to be very efficient for genetic mapping is a technology based on polymerase chain reaction (PCR). PCR-based technology that was first developed and widely used to study plant genetics is the technique of random amplified polymorphic DNA (RAPD) [8]. Genetic mapping which combines the pseudo-testcross strategy and RAPD markers were first reported in Eucalyptus plant as in [3]. Genetic linkage maps in rubber plant have been reported by using RFLP markers, AFLP markers, SSR markers and isozim markers (RFLP) [9], [10], [11]. So far 
there is no report about QTL mapping associated with latex yield component. So, the objectives of the research were to get the linkage map especially for PB 260 as female parent, and to know RAPD markers and morphology markers which associated with QTL controlling latex yield component.

\section{MATERIALS AND METHODS}

The research was carried out at the Rubber Research Center Sei Putih Medan and PPKS Siantar, North Sumatera. It took place in 2006-2007.

\section{A. Plant Material}

Two first generation populations was used in this research namely A populations: progenies of PB $260 \times$ PN 7111 as many as 22 plants (1A-22A), and C population : progenies of PB $260 \times$ PN 7 as many as 20 plants (1C-20C). PB260 is superior clone with high yield which often used as parent plant on a crossing. Whereas PN 7111 and PN 7 are germ plasms with very low yield. The first generation plants were planted in August-September 1998, at a distance $2 \mathrm{~m}$ x $2 \mathrm{~m}$ in Experiment Garden, Rubber Research Sei Putih Medan. PB 260, PN 7111 and PN 7 as parent plants were also used in this research.

\section{B. RAPD Assay}

RAPD assay used genomic DNA of each sample plants. DNA was isolated according to [12] which is a modification of the method [13]. Amplification reaction were carried out as in [8] with some modifications. PCR reactions were performed using materials supplied by Promega and RBC (Real Biotech Corporation). Random 10-bp primers were obtained from Operon Technologies Inc. PCR amplification used a thermal cycler Gene Amp PCR 2400 (Perkin Elmer), with thermal cycles were repeated 45 times, programmed $1 \mathrm{~min}$ at $94{ }^{\circ} \mathrm{C}$ (denaturation), $1 \mathrm{~min}$ at $37{ }^{\circ} \mathrm{C}$ (annealing) and $2 \mathrm{~min}$ at 72 ${ }^{\circ} \mathrm{C}$ (elongation) followed by a final elongation for $4 \mathrm{~min}$ at $72^{\circ} \mathrm{C}$. RAPD products were analyzed by electrophoresis in $1.4 \%$ agarose gels for 70 minutes at $50 \mathrm{~V}$ voltage, using a buffer 1X TAE (40 mM Tris, 20mM glacial acetic acid, 1 mM EDTA pH 8.0). 1 kb DNA ladder (Promega or RBC) was used as a marker to estimate amplification fragments. Furthermore, gels were soaked in a $\mathrm{EtBr}$ solution for 30 minutes and in distilled water for 10 minutes. The DNA bands were visualized with trans-luminator UV and documented with Polaroid films.

\section{Primer Screening}

A total of 80 random primers decamer (Appendix 6) (Operon Technologies Inc.) were screened againts the two parents. RAPD fragments that are polymorphic between the two parents can be detected. A total of 25 primers were selected during this step. Selected primers were used on the mapping population.

\section{Scoring of RAPD Markers}

Segregation of RAPD markers in the mapping population was recorded. Segregating RAPD markers were identified by the manufacturer primer code corresponding to a particular 10-basa sequence, followed by a number indicating the fragment size in base pairs. Following the fragment size was separated by a slash. The presence or absence of DNA bands for each primer was scored manually. Data used as binary data which equal to 1 for the presence of DNA band and the value 0 for the absence of a homologous DNA band. The parental origin of the marker was also recorded. Two separate data sets were obtained, one for each parent. Furthermore, it was anayzed using the chi-square test ( $\mathrm{P} \square 0.05$ ) to get the its segregation ratio [14]. In the pseudo-testcross configuration markers are present in one parent and absent in the other or vice versa, and are expected to segregate $1: 1$ in the first generation progenies.

\section{E. Construction of Genetic Linkage Map}

RAPD markers segregating 1:1 was used to construct a linkage map. Linkage map was constructed using software Mapmaker / EXP 3.0, model backcross [15], [16], at LOD 3.0. The distance map unit (cM centi Morgan) used Haldane mapping function [17]. Linkage groups were obtained with command group. Command compare to determine the best sequence in groups with three or more loci. Best locus sequence of each group was determined by linkage maximum log likelihood of several possible sequences. Command map is used to view the map loci and the distance between the two loci. Command draw is used to obtain images of map.

\section{F. Component of latex yield}

There are eight variables were observed, namely latex yield, girth, bark thickness, the amount of latex vessel rings, diameter of latex vessel, plugging index, sucrose content and inorganic phosphate content.

\section{G. Morphological Character}

Morphological characteristics of each plant at A and C population were observed directly in the field. The characters were leaf shape, leaf scintillation, leaf edge, surface density and type of branch. The morphological characters are often observed on rubber plant as in [18], [19]. Morphology characters having segregation ratio 1:1 were used in this research.

\section{H. Identification of $Q T L$}

To construct the QTL map associated with the high latex yield, it is necessary data quantitative of latex yield components, data markers and linkage maps of parent (PB 260). Identification of QTL was done using single marker analysis by t-test [2]. Single marker analysis was also performed to determine association between the morphological characters and the latex yield components.

\section{RESULTS AND DISCUSSIONS}

\section{A. Primer Screening and Markers Scoring}

Primer Screening and Markers Scoring Primer screening was carried out using both parents. Of the 80 primers screened, $25(31,25 \%)$ did not detect any visible polymorphism in both parents, $17(21,25 \%)$ did not yield any amplified product and $38(47,5 \%)$ uncovered at least one RAPD fragment polymorphism. From these 38 primers, 25 primers were used at RAPD reaction of their progenies. A total of 94 RAPD markers were scored on the A mapping population, yielding an average of 3.76 markers per selected primer. RAPD fragments sizes ranged from 250 to $2200 \mathrm{bp}$. From 94 RAPD 
markers, 50 markers were polymorphic and 40 markers were monomorphic.

\section{B. Genetic Linkage Map}

Based on the overall PCR reactions using 25 polymorphic primers were obtained 30 markers having segregation ratio 1:1 on A population. It consisted of 20 markers for linkage map of female parent (PB260) and 10 markers for linkage map of male parent (PN 7111). On C population were obtained 19 markers for linkage map of PB260. Pooled markers data of A and $\mathrm{C}$ populations were obtained 15 markers for linkage map PB260. Construction of linkage maps for PB 260 at LOD 3.0 was only obtained one linkage group. There were only two markers linked namely 015-1300 and 015-1500 with a distance $4.8 \mathrm{cM}$ in A population and $2.4 \mathrm{cM}$ in the combined $\mathrm{A}$ and $\mathrm{C}$ populations (Fig. 1).

The entire document should be in Times New Roman or Times font. Type 3 fonts must not be used. Other font types may be used if needed for special purposes. Recommended font sizes are shown in Table 1.
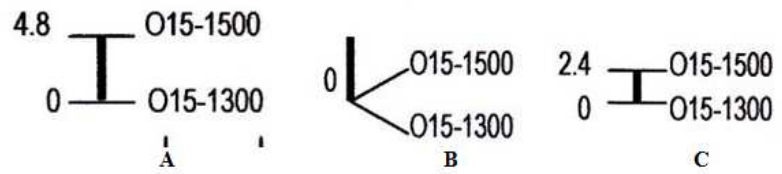

Fig. 1 Genetic linkage map of PB 260 at LOD 3.0

a. based on RAPD markers of A population

b. based on RAPD markers of $C$ population

c. based on RAPD markers of $\mathrm{A}$ and $\mathrm{C}$ populations

Construction of linkage maps for PB 260 using data of 20 segregated RAPD markers on A populations at LOD 1.5 were obtained three linkage groups. In group 1 there were six linked RAPD marker loci. In group 2, there were 3 loci, and in group 3 there were two loci. While 9 other loci couldn't be mapped at LOD 1.5 (Fig. 2). Linkage map for PN 7111 can only be constructed with a minimum LOD 1.5, and was obtained 1 linkage group consisted of 2 marker loci, namely C20-250 and H02-700 with the distance $30.3 \mathrm{cM}$.
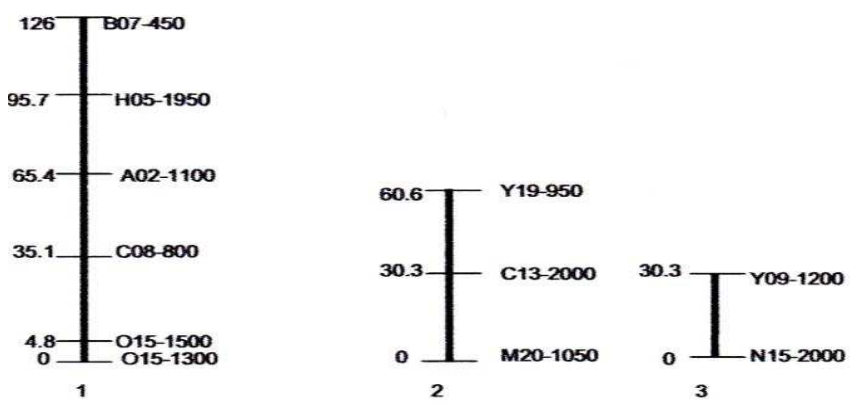

Fig 2. Genetic linkage map of PB 260, constructed using 20 RAPD markers of A population at LOD 1.5

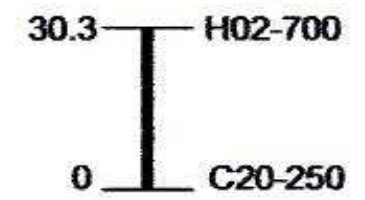

Fig. 3 Genetic linkage map of PN7111, constructed using 10 RAPD markers of A population at LOD 1.5
Construction of linkage maps for PB 260 using 15 RAPD markers of combined A and C populations at LOD 2.5 were obtained two linkage groups (Fig. 4). The minimum distance between markers was $2.4 \mathrm{cM}$, while the maximum distance between markers was $32.3 \mathrm{cM}$. It was obtained three linkage groups at LOD 1.5 (Fig. 5).

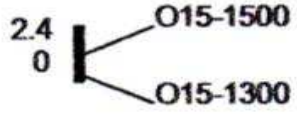

1

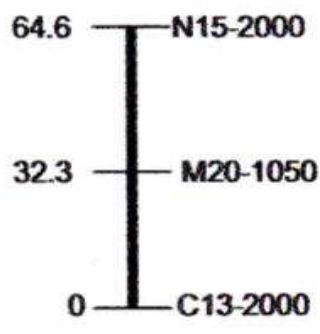

2
Fig. 4 Genetic linkage map of PB 260, constructed using 15 RAPD markers of combined A and C population at LOD 2.5.

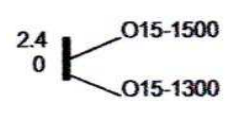

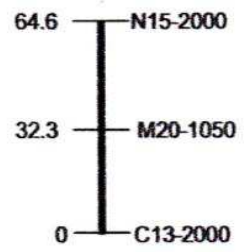

2

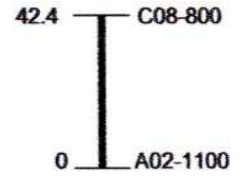

3
Fig. 5 Genetic linkage map of PB 260, constructed using 15 RAPD markers of combined $\mathrm{A}$ and $\mathrm{C}$ population at LOD 1.5

The genetic linkage map obtained was still far from ideal map criteria. Genetic linkage map is ideal if the number of linkage groups is equal to the haploid number of chromosomes, and the density of markers is high on a linkage group. Hevea brasiliensis have $\mathrm{n}=18$ chromosomes, and therefore 18 linkage groups were expected in each map. The number of linkage groups of this map was low, and the distance between markers was far. These were due to the number of screened primers wasn't much. According to [20] construction of linkage map of a plant at first did not immediately get a map of the high density and the number of linkage groups according the number of haploid chromosomes. Linkage groups obtained were generally larger or smaller than the number of haploid chromosomes.

\section{QTL of Latex Yield Components}

Identification of QTL was performed using single marker analysis. RAPD markers segregating 1:1 were analyzed one by one to detect QTL linked with RAPD markers. According to Liu [2], single marker analysis is based on a comparison between the average value of a quantitative trait and marker genotypes through simple regression, $t$ test, analysis of variance and the likelihood ratio test. QTL is determined near markers if the value of a quantitative trait significantly different among the genotype markers. In this study, the existence of QTL for latex yield components was performed using the t-test. Not only using RAPD markers data but also used data of segregation simple morphological character segregating 1:1 in A population. The result of single marker analysis by t-test for RAPD markers segregating 1:1 in A population are presented in Table 1. 
Based on the results of the t-test was known that at the marker C13-2000 there was differences in the average of latex yield between allele 1 (presence of DNA fragment) and allele 0 (absence of DNA fragment). C13-2000 marker was marker that present on the female parent (PB 260) but absent on the male parent (PN 7111). So it was suspected that there was a QTL of latex yield which located near the locus C13-2000. Marker C13-2000 also segregated 1:1 in C population. Basedon the results of t-test on the combined populations $\mathrm{A}$ and $\mathrm{C}$ showed that the average of latex yield for allele 1 and allele 0 of locus C13-2000 was significantly different (t value 2.077 and $\mathrm{p} \mathrm{0.044).}$

TABLE I

RESULT OFT-TEST FOR LATEX YIELD (g/p/s) AT EACH RAPD MARKER ON A POPULATION

\begin{tabular}{lcccl}
\hline $\begin{array}{l}\text { RAPD } \\
\text { Marker }\end{array}$ & $\begin{array}{c}\text { Average of latex } \\
\text { yield on } \\
\text { Alel }\end{array}$ & $t$ value & $P$ \\
\hline \multicolumn{5}{c}{1} \\
A02-1100 & 4.274 & 4.566 & -0.263 & 0.795 \\
B07-450 & 4.720 & 4.089 & 0.573 & 0.573 \\
C08-800 & 4.437 & 4.430 & 0.007 & 0.995 \\
C08-1000 & 4.204 & 4.564 & -0.314 & 0.757 \\
C13-2000 & 5.580 & 3.478 & 2.092 & 0.049 \\
C19-1200 & 4.634 & 4.192 & 0.400 & 0.694 \\
C20-400 & 4.574 & 4.316 & 0.233 & 0.818 \\
D01-600 & 4.565 & 4.342 & 0.199 & 0.844 \\
D05-400 & 4.284 & 4.695 & -0.359 & 0.723 \\
H05-1950 & 4.671 & 4.195 & 0.433 & 0.670 \\
M20-1050 & 4.072 & 4.684 & -0.549 & 0.589 \\
N15-2000 & 4.081 & 4.727 & -0.588 & 0.563 \\
O15-1300 & 4.763 & 4.205 & 0.500 & 0.623 \\
O15-1500 & 4.642 & 4.259 & 0.346 & 0.733 \\
O20-1300 & 3.693 & 5.050 & -1.271 & 0.218 \\
W19-550 & 4.246 & 4.620 & -0.339 & 0.738 \\
W19-750 & 4.090 & 4.671 & -0.521 & 0.608 \\
W19-1100 & 3.606 & 4.906 & -1.170 & 0.256 \\
Y09-1200 & 4.237 & 4.717 & -0.429 & 0.673 \\
Y19-450 & 3.959 & 5.003 & -0.962 & 0.347 \\
Y19-950 & 4.848 & 3.834 & 0.922 & 0.367 \\
\hline
\end{tabular}

Variables that have been previously known to correlate significantly with the latex yield, t- test was also performed to know association with C13-2000 marker. Based on the results of the t-test was known that the average of the amount of latex vessels between the plants having allele 1and having allele 0 was significantly different ( $\mathrm{t}$ value 3,149 , $\mathrm{p}$ value 0,005 ). Ttest results for the combined populations $\mathrm{A}$ and $\mathrm{C}$ to the character of the amount of latex vessels also showed the same result (t value 3,094, $\mathrm{p}$ value 0.004). QTL identification through single marker analysis has the disadvantage that the exact location of QTL can't be known and in this case QTL was mapped based on estimation. It is presented as in Fig. 6.

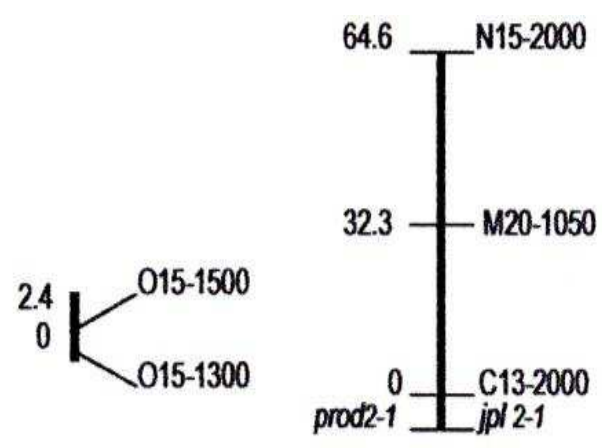

Figure 6. Plot QTL on the linkage map of PB 260

Single marker analysis was also performed for morphology characters. Based on the analysis of segregation of morphology characters have been known that some morphology characters segregating 1:1 on A population. The result of single marker analysis of some morphology characters showed that leaf shape character associated with girth, bark thickness and the amount of latex vessels. The plants of A population with leaves elliptical had the average of girth, bark thickness and the number of latex vessels were significantly higher than plants with leaves oval. Character of leaf edge associated with plugging index. The first generation progenies in A population with a wavy leaf edge had a plugging index significantly lower than plants with a flat leaf.

\section{CONCLUSIONS}

Linkage map of PB 260 was constructed on LOD 3.0 yielded 1 linkage group, on LOD 2.5 yielded 2 linkage group. Based on single marker analysis through t-test was known that marker C13-2000 linked with character of latex yield and the number of latex vessel. Leaf shape character linked with girth, bark thickness, and the number of latex vessel. Character of leaf edge linked with plugging index.

\section{ACKNOWLEDGMENT}

We would like to thank Dr. Karyudi who have given permission to conduct this research.

\section{REFERENCES}

[1] M. Lee. 1995. DNA markers and plant breeding programs. Adv Agron 55:265-344.

[2] B.H. Liu. 1998. Statistical Genomics : Linkage, Mapping and QTL Analysis. Washington: CRC Pr.

[3] D. Grattapaglia, R. Sederoff . 1994. Genetic linkage maps of Eucaliptus grandis and Eucaliptus urophylla using pseudo-test- cross: mapping strategy and RAPD markers. Genetics. 137:1121-1137.

[4] Cirad. 2004. Rubber tree genome mapping and tagging of useful genes. [abstrak]. Plant Genomic at Cirad.

[5] E. Okogbenin, M. Fregene. 2001. QTL mapping in an F1 population from non-inbred parents in cassava (Manihot esculenta) : yield and root quality traits. [abstrak]. http:// www. Ciat/

[6] C. Liu , M. Mei. 2003. Construction of a lychee genetic linkage map based on RAPD markers. [abstrak]. XXVI International Horticultural Congress: Biotechnology in Horticultural Crop Improvement; Achievements, Opportunities and Limitations.

[7] B.A. Zuniga, P. Scott , K.J Moore, D. Luth, E.C. Brummer. 2004. Quantitative trait locus mapping of winter hardiness metabolites in auto tetraploid alfalfa (M. sativa). [abstrak].

[8] JGK. Williams, A.R. Kubelik, K.J. Livak, J.A. Rafalsky, S.V. Tingey 1990. DNA polymorphism amplified by arbitrary primers are useful as genetic markers. Nucleic Acid Res 18:6531-6535.

[9] M. Seguin, D. Lespinasse, M. Rodier, A. Leconte, Nicholas. 1995. Development of a RFLP based genetic linkage map in rubber tree using a F2 population. [abstrak]. Plant Genom III Conference. San Diego

[10] M. Seguin, M. Rodier-Goud, D. Lespinasse. 1997. Mapping SSR markers in rubber tree (Hevea brasiliensis) facilitated and enhanced by heteroduplex formation and template mixing. [abstrak]. Plant \& Animal Genome V Conference. San Diego. 12-16 January 1997.

[11] D. Lespinasse et al. 2000. A saturated genetic linkage map of rubber tree (Hevea spp) based on RFLP, AFLP, microsatellite and isozyme markers. [abstrak]. Theor Appl Genet 100:127-138.

[12] Nurhaimi-Haris, S. Woelan, A. Darussamin. 1998. RAPD analysis of genetic variability in plant rubber (Hevea brasiliensis Muell Arg) clones. Menara Perkebunan 66(1):9-19.

[13] C. Orozco-Castilo, K.J. Chalmers, R. Waugh, W. Powell. 1994. Detection of genetic diversity and selective gene introgression in coffe using RAPD markers. Theor Apll Genet 87: 934-940. 
[14] M. Jusuf. 2001. Genetika I : Struktur dan Ekspresi Gen. Jakarta : Sagung Seto. p40-41..

[15] E.S. Lander et al. 1987. Mapmaker: an interactive computer package for constructing primary genetic linkage maps of experimental and natural populations. Genomics 1:174-181.

[16] S. Lincoln, M.J. Daly, E.S. Lander. 1992. Construction Genetic Linkage Maps with MAPMAKER/EXP 3.0 Ed ke-3. USA: Whitehead Institute. Research Technical Report.

[17] J.B.S. Haldane. 1919. The combination of linkage values and the calculation of distances between the loci of linked factors. Genet 8:299-309

[18] M.J. Dijkman. 1951. Hevea. Thirty Years of Research in the Far East. Florida: University of Miami Pr.

[19] S. Woelan. 2002. Pengenalan klon karet unggul baru penghasil latekskayu. Balai Penelitian Karet Sungai Putih.

[20] E. Irwansyah. 2004. Peta pautan genetik marka RAPD dan analisis QTL kelapa sawit menggunakan populasi silang balik generasi pertama menuju perbaikan kualitas minyak [disertasi]. Bogor: Sekolah Pascasarjana, Institut Pertanian Bogor 